\title{
TOWARDS A DECONSTRUCTED CURRICULUM: RETHINKING HIGHER EDUCATION IN THE GLOBAL NORTH
}

\begin{abstract}
The purpose of this article is to argue for the deconstruction rather than the decolonisation of the neocolonial curriculum. Globalisation facilitates the democratisation of higher education, which is now accessible to more people than ever before, but globalisation also facilitates the expansion of the ideological dominance of the Global North over the Global South by means of the neocolonial curriculum. Contemporary attempts to decolonise Global South curricula are proceeding very slowly. We propose an alternative, the deconstruction of the Global North curriculum, i.e. a radical change to the Global North curriculum that exploits the neoliberal imperative to maximise profit in order to undermine the neocolonial curriculum. We use two case studies - Frantz Fanon and Çiğdem Kağitçibaşi - to demonstrate how the deconstruction of the Global North curriculum can be achieved, by the prioritisation of theory and practice that are sensitive to context.
\end{abstract}

KEY WORDS: Curriculum, Decolonisation, Deconstruction, Frantz Fanon, Çiğdem Kağitçibaşi 


\section{Introduction: The Neocolonial Curriculum}

As the title of Gayatri Chakravorty Spivak's (2013) An Aesthetic Education in the Era of Globalization implies, she is concerned with aesthetic education in the twenty-first century. Aesthetic education is the thesis that there is a causal relation between aesthetic or artistic experiences on the one hand and moral and political development on the other. Spivak (2013) characterises the twenty-first century as the era of globalisation, which she contrasts against the preceding era: two worlds (North and South) have replaced three (First, Second, and Third), global has replaced postcolonial, digitally-assisted postmodernism has replaced modernism, and neoliberal policy has replaced ideological politics. Spivak links the aesthetic to the imagination and draws attention to the importance of the double bind. The double bind is a theoretical framework in which two concepts in binary opposition both contradict and construct one another. The framework is a development of Derrida's (1997; 2001) différance, which is a core component of deconstruction, the meta-framework we discuss in $\S 2$. The double bind is particularly important to global aesthetic education because while the aesthetic encourages maximal use of the imagination, globalisation encourages conformity to neoliberal norms (Spivak 2013). The distinguishing feature of the double bind is not the obvious point that these imperatives draw the individual in opposite directions, but that the aesthetic and the global construct as well as contradict one another and Spivak's project is the articulation of a poststructural theory of aesthetic education that both recognises and exploits the double bind at the centre of global aesthetic education.

In a similar manner to that in which globalisation both facilitates and undermines aesthetic education so it both facilitates the democratisation of higher education - which is more accessible to more people than ever before - and sustains and expands the ideological dominance of the Global North over the Global South by means of the neocolonial 
curriculum. Neocolonial hegemony has been reinvigorated by the neoliberal export of education, which began in the United Kingdom with the opening of the University of Nottingham's Malaysia Campus in 2000 and has accelerated ever since. The first part of the University of Oxford's (2015:3) recent report on international trends is entitled 'New Developments in Higher Education', half of which is concerned with 'Universities as international brands'. The information on global branding begins with a section entitled 'International branch campuses are expanding to include non-traditional countries' (2015: 10). Non-traditional is not defined, but appears to refer to countries where students are unlikely to be in a financial position to afford to study in the Global North, but will be in a financial position to pay their fees if the Global North comes to them. The examples provided are: Ghana, Mauritius, Tunisia, and Morocco. The report claims that there were two hundred and twenty international branch campuses - most of which have a home in the Global North and a host in the Global South - in February 2015, but a more recent study by the CrossBorder Education Research Team identifies two hundred and forty-eight in January 2017, excluding those under development (Maslen 2015; Lane \& Kinser 2017). The number of UK international branch campuses almost doubled from 2008 to 2012 and according to Oxford (2015: 10), the expansion 'has been timed to fit with the projected expansion in the number of students entering higher education in Asia and Africa.'

Shahjahan (2014: 221) defines the neoliberal environment as one where 'economic rationality operates as the overarching frame for understanding, evaluating and governing social life.' Those institutions delivering higher education within this environment adopt the explicit and implicit biases of neoliberalism and reproduce power structures that reduce all human values to economic value and reward competition over cooperation. An example of the implicit bias inherent in the neoliberal world view is the stated goal of the internationalisation of higher education. The connotation of the term is some kind of 
democratisation, i.e. the recognition of a multiplicity of perspectives; making higher education more representative; the inclusion of global perspectives. The denotation in reductive neoliberal terminology is the expansion of the university into the global market, i.e. attracting international students (who often pay substantially more than their local counterparts) in order to expand the consumer base and maximise profit. Gyamera and Burke (2018: 450) describe the impact of neoliberalism on education as establishing a 'hegemonic and common sense' discourse that propagates a standpoint based on the white/Western/European/Anglo-American understanding. Not only does the neoliberal imperative to maximise profit exclude appreciation of difference, complex inequality, and the reconstruction of group status and realities, but it also naturalises existing levels of marginalisation and social division. The combination of profit and naturalisation has made neoliberalism particularly difficult to resist and the consequence for higher education has been a neocolonial curriculum that reinforces the colonial curricula of the past. The perception of the neocolonial curriculum as extending the dominance of the Global North over the Global South has produced appeals to match the political independence achieved in the second half of the twentieth century with an ideological independence at the beginning of the twenty-first century. The phrase most commonly used to describe this process is decolonising the curriculum.

\section{Theoretical Framework: Decolonisation versus Deconstruction}

Decolonising the curriculum standardly involves confronting the academic mentality that ignores indigenous theorists and scientists and aims at placing indigenous information resources and research cultures on an equal footing with those imposed during the colonial era. Gyamera and Burke (2018) argue that true internationalisation in higher education would 
mean integrating (local) cultural dimensions into all aspects and functions of the institution, creating a space for interdependence and the exchange of knowledge. In consequence, a decolonisation of the Global North curriculum requires a bespoke approach in each country that had adopted the neocolonial curriculum. To take two former British colonies as examples, the multiplicity of perspectives required in Ghana will be very different from the multiplicity of perspectives required in Mauritius. A relentless diversification of curricula in the Global South may cause a different set of problems, however, in addition to which it seems likely to take a long time to complete. Winberg and Winberg (2017) suggest a social justice approach to decolonisation. Their study concluded that a curriculum which provides students with the opportunity to explore social justice in the context of the various components of their degrees is likely to promote the decolonisation of both those degrees and of the wider curriculum of which they are a part. Collins (2017) and Mercer-Mapstone and Mercer (2018) have argued for a still broader approach, as they find simplistic binary explanations which draw rigorous boundaries between ingroup and outgroup, to reinforce the neocolonial hegemonic structure. They claim that oppositional and hierarchical binaries also undermine criticality and objectivity. In the post-truth society of today, this could be especially damaging as students will not be encouraged to see the world through a sceptical lens, and/or employ scepticism to engage critically with contradicting sources of information and knowledge.

The evidence available seems to suggest that decolonisation has thus far proceeded at a very slow rate, if at all. Gahman and Legault (2017) discuss the situation in Canada, claiming that conceptions of decolonisation have had little impact on university officials and academics, and that efforts to integrate indigenous knowledge into the curriculum have been both limited and ineffective. Of perhaps greater concern within the UK is the close coincidence of two trends in higher education: (a) the recognition of the need to decolonise 
the curriculum and (b) the rapid increase in the number of international branch campuses. Protest movements such as \#whitecurriculum in 2014 and \#RhodesMustFall in 2015 may have revealed the flaws in the home curriculum, but that curriculum is being exported to host countries at an increasing rate. In Lane and Kinser's (2017) database, fifteen of the host countries for UK universities are either former colonies, part of the Global South, or both and this number does not include campuses under development. When one considers home universities in the Global North beyond the UK, the problem is significantly more substantial. Gyamera and Burke (2018) argue that the neoliberal definition of excellence in higher education in economic terms is depriving institutions of the autonomy to determine the curriculum in the Global South, which exacerbates the situation.

Our proposal for the deconstruction of the Global North curriculum recognises the coincidence of the above two trends in higher education with a third, which has occurred both within the academy and in society more generally and is known variously as new scepticism, the post-fact or post-truth era, or the era of alternative facts. The idea that language does not provide direct access to reality or that truth is immanent rather than transcendent is not a feature of this century, but the last. In the nineteen sixties poststructuralist works such as Foucault's (2001) Madness and Civilization: A History of Insanity in the Age of Reason and Derrida's (1997) Of Grammatology questioned the foundations of knowledge upon which the Enlightenment had been built. Sociologists like Beck (1992) and Giddens (1996) developed these ideas in the late nineteen eighties, conceiving of the loss of faith in scientific practice and the questioning of established expertise as features of late modernity, an inevitable consequence of the loss of certainties at the end of the nineteenth century. Early in the nineteen nineties, feminist theorists such as Harraway (1991), Braidotti (1991), and Oliver (1995) contributed to this intellectual movement by challenging objectivity in both science 
and philosophy, articulating a critical epistemology that exposed the masculine assumptions of each. This kind of scepticism accelerated exponentially with the widespread use of handheld devices in the twenty-first century and social media has been employed to both question expertise and disseminate alternative facts. The phrase alternative facts was popularised by Kellyanne Conway on 22 January 2017, when she attempted to defend Sean Spicer's exaggeration of public support at the inauguration of Donald Trump as President of the United States, held two days beforehand (Blake 2017). Conway, like Spicer, was widely mocked and the term became synonymous with post-truth and post-fact, which had already been applied to the Conservative Government's Brexit campaign in the UK and Trump's presidential campaign in the US. Our claim is that the era of alternative facts - a time of renewed and revitalised scepticism - provides an ideal opportunity to implement radical change in higher education. We describe this radical change as deconstructing the curriculum.

As noted in $§ 1$, Spivak's double bind is a development of différance, which is the lynchpin of Derrida's (1997; 2001) deconstruction, a meta-theoretical framework that seeks to reconceptualise binary oppositions by means of rigorous analysis of the internal logic that maintains the structure of the polarity of the concepts. Deconstructive criticism is typical of poststructuralism in having a reputation for blithe and needless complexity, but its premise is relatively straightforward: human beings (subjective experience) can only gain access to the real world (objective reality) through concepts, which are articulated through language. The problem, which stems from curiosities such as the fact that languages not only use different words for the same concept but have different concepts that cannot be translated exactly, is that no human language and therefore no human conception maps perfectly on to reality. Différance combines difference with deferral to communicate the idea that language is 
composed of signifier-signifier relations (word to word) rather than signifier-signified (word to object), that these signifier-signifier relations are in state of constant change, and that meaning is therefore never completely constituted. Every concept is thus not only identical to itself, but also different from itself, being to some extent constituted by its binary opposite. Différance is employed to draw attention to and to undermine logocentrism, the epistemological vice of believing that concepts have their origin in the structure of reality, which is made present to human beings by means of language, and that a particular language provides unique and direct access to reality. Deconstruction as a practice typically involves extrapolating the logic underpinning a pair of binary oppositions in order to expose logocentric conceptions of the distinction as interpretations rather than presentations of reality. In our case, we propose a reconceptualisation of the binary opposition Global North/Global South. Decolonisation has prioritised Global South over Global North in order to effect democratisation of the curriculum. When considered in terms of the aim of democratisation, however, the logic of this distinction reveals that the emphasis for reform is more effectively achieved by prioritising the Global North, i.e. curriculum decolonisation is more likely to be achieved by reversing its prioritisation of the culture, circumstances, and commitments of the Global South.

The deconstruction of the curriculum exploits the coincidence of the following three trends: (i) the call to change the Global North curriculum, (ii) the neoliberal expansion of the Global North curriculum into the Global South, and (iii) scepticism in the era of alternative facts. Deconstructing the curriculum involves first taking advantage of the new scepticism to make radical changes to the Global North curriculum and then taking advantage of the neoliberal model already in place to export a decolonised curriculum to the Global South. The neoliberal model for the export of education from Global North to Global South is wellentrenched, being perpetuated by aggressive marketing, and unlikely to be discontinued in the 
near future. Deconstruction is distinct from decolonisation in that it requires changes in the home curriculum rather than - or before - the host institutions. The advantage of deconstruction over decolonisation is that it employs rather than resists the neoliberal model and is in consequence more likely to reach more universities in the Global South more quickly. The framework solves the problem posed by the double bind: globalisation ensures that Global North higher education reaches more people than ever before, but the higher education being adopted in the Global South is genuinely internationalised. The question is then how to change the Global North curriculum in such a way that that it achieves goals such as diversity, representativeness, and inclusivity without resorting to the relentless diversification with which we initially characterised curriculum decolonisation.

We thus argue that deconstruction must start by focusing on context - not a particular context, but sensitivity to context and applicability to different contexts. In the next two sections, we present two case studies. The first provides an example of the failure of the decolonisation of the curriculum in the marginalisation of the oeuvre of Frantz Fanon. The second provides the theoretical underpinning of curriculum deconstruction, Çiğdem Kağitçibaşi’s contextual-developmental-functional approach.

\section{Case Study: Frantz Fanon}

Frantz Fanon was born in Fort-de-France in Martinique on 20 July 1925. He was taught by Aimé Césaire, but his secondary education was interrupted when he decided to join the Free French Forces in August 1943 (Macey 2012; Pirelli \& Love 2015). Fanon took part in the Allied invasion of the south of France in 1944 and was wounded by a mortar shell during the Battle of Alsace. He returned to Martinique to complete his baccalaureate before enrolling in the medical school at Lyon, where he attended Maurice Merleau-Ponty's philosophy lectures 
while specialising in psychiatry. He graduated in 1951 and published Black Skin, White Masks (1967), a literary, psychological, and phenomenological account of black experience and anti-black racism, the following year. Fanon qualified as a practicing psychiatrist in 1953 and was appointed head physician on duty at Blida-Joinville hospital in Algeria (Cherki 2006; Hudis 2015; Pirelli \& Love 2015). The Algerian War began in 1954 and he found his position as a French medical official untenable. Fanon resigned in December 1956 and was recruited by the National Liberation Front (FLN) as first the director of their press service and then a diplomat. Fanon published A Dying Colonialism (1965b), a political and sociological commentary on the revolution-in-progress, in 1959. He was diagnosed with leukaemia the next year and sent to the Soviet Union for treatment in January 1961. The Central Intelligence Agency facilitated his travel to Washington, D.C. for further treatment in October. He died of double pneumonia on 6 December 1961, three days after the publication of The Wretched of the Earth (1965a), a political manifesto that argued for the need to counter colonial oppression with revolutionary violence (Geismar 1971; Gordon 2015; Macey 2012).

The Wretched of the Earth received an icy reception in France, a warmer one in Africa, and was embraced with enthusiasm by black America. By the late nineteen sixties, Fanon was also popular in Quebec, Cuba, Italy, Iran, and Mozambique and the first biography, David Caute's Fanon, was published as part of Fontana's Modern Masters series in 1970. His fame (or notoriety) was nonetheless short-lived, to the extent that former colleague Cherki (2006: 191) described him as having ‘fallen into oblivion’ by 1971. Ironically, although the main reason for Fanon's poor reception in France was his defection to the FLN during the Algerian War, his legacy in post-independence Algeria was limited because he was neither a communist nor a Muslim - nor even an Arab or Algerian. Biographer Macey (2012) states that The Wretched of the Earth was regarded as dated by the 
nineteen eighties, with the remainder of interest in Fanon's work focused on Black Skin, White Masks, which was being more widely read than at the time of publication. Hudis (2015: 1) begins his biography with the claim that Fanon's name 'went viral in December 2014' - revived by Black Lives Matter in response to the death of Eric Garner - after being 'consigned to debates over postcolonialism, difference and alterity for many years.' Similarly, Gibson and Beneduce (2017) write of a renewal of interest in Fanon during the Arab Spring (2010-2012) and the \#FeesMustFall student protests in South Africa (20152016). Notwithstanding, Fanon remains at the margins of the canon, a 'surprisingly enigmatic and elusive figure' (Macey 2012: 7) who produced 'a body of work often viewed as inadmissible' (Cherki 2006: 4).

When Fanon is included in the syllabus, it is usually as part of either postcolonial studies or existentialist philosophy and the full extent of his marginalisation is revealed when one considers two of his contemporaries, Edward Said and Albert Camus. Not only are both substantially better known, but they are widely acknowledged as canonical figures within their respective disciplines. The comparison with Camus is particularly telling because Camus was a French-Algerian, died the year before Fanon at the age of forty-six, and was a vociferous opponent of the anti-colonial violence justified in The Wretched of the Earth (Foley 2008). Despite his rejection of the philosophical label, Camus is taught as one of the key existentialist thinkers. In contrast, Webber (2018) is one of very few contemporary existentialists to include Fanon in his analysis of French existentialism, alongside Jean-Paul Sartre and Simone de Beauvoir. The superficial reasons for this marginalisation are obvious: Fanon's oeuvre is both small and difficult to classify. All three of his monographs are not only essentially interdisciplinary, but actively resist what Gordon (2014) calls disciplinary decadence, the practice of treating one's own discipline as if it provides a privileged access to reality to which other disciplines can only aspire - and there may be a relationship between 
Fanon's resistance and the particular sensitivity to context of his work for whose significance we shall argue in $\S 5$.

Fanon's biography contributed even more to his marginalisation than his bibliography. First, his example as an active revolutionary presented a global threat. Amidst a geopolitical climate of heightened tensions in the Cold War, increasing pressure on European countries to dismantle their empires, and the rise of direct Civil Rights action in the US, Fanon was participating in an armed struggle and encouraging others at home and abroad to do the same. In putting the Third World above - and indeed in opposition to - the First and the Second Worlds, he was a danger to both the capitalist West and communist East (Macey 2012). The end of the Cold War provided a convenient excuse to label his politics irrelevant and focus interest on the less incendiary Black Skin, White Masks. Second, the circumstances of Fanon's life determined the circumstances of the composition of his three monographs: the first was written without assistance while he was a student, the second while he was evading assassination, and the third literally as he lay dying. These circumstances, including the frenetic pace at which his writing was dictated, have opened the texts themselves up to a variety of criticisms: sexism in Black Skin, White Masks (Macey 2012) factual inaccuracies in A Dying Colonialism (Hudis 2015), and promoting mass violence in The Wretched of the Earth (Gibson \& Beneduce 2017). One might thus say that Fanon's exclusion from the Global North curriculum was overdetermined.

\section{Case Study: Çiğdem Kağitçibaşi}

Çiğdem Kağitçibaşi was born in Elazig, in eastern Turkey, on 29 January 1940. Her secondary education was completed at the American College for Girls in Istanbul and her tertiary education in America, at Wellesley College and the University of California, 
Berkeley. Her PhD included one of the first cross-cultural studies in psychology, a comparison of American and Turkish high school students' attitudes and family perceptions. Kağitçibaşi spent her entire teaching career in Turkey, at first the Middle East Technical University, then Boğaziçi University, and finally Koç University. Her return to Turkey was motivated by the desire to support student learning and foster research in her native country, but she retained her international status throughout her career, publishing widely and taking an active role in a variety of international academic bodies. Kağitçibaşi was President of the International Association for Cross-Cultural Psychology (1990-1992), President of the Turkish Psychological Association (1992-1994), a founding member of the Academy of Sciences in Turkey (1993), Vice President of the International Social Science Council (20022008), and UNESCO Chair on Gender Equality and Sustainable Development (2015). She died on 2 March 2017, aged seventy-seven (Aycan \& Cemalcilar 2018; Poortinga 2018). In contrast to Fanon, Kağitçibaşi's work had a great impact on her discipline, particularly in social, cultural, and developmental psychology. We seek to extend this impact beyond psychology by explaining how her contextual-developmental-functional approach, which is embedded within her theory of social change, provides a methodology for the deconstruction of the curriculum, shifting priority away from Western-based sources of knowledge to those that are sensitive to context.

Kağitçibaşi (2017) revealed the beginning of her inquiry into non-Western psychology as her reading of The Authoritarian Personality, a sociological work written by Theodor W. Adorno, Else Frenkel-Brunswik, Daniel Levinson, and Nevitt Sanford, first published in 1950. The book made her realise that submission to authority in the Western sense could easily be mistaken for respect for authority in cultures with more of an emphasis on social cohesion, in which it could be conceived of as an expression of decency and respect for one's elders. The question of different attitudes to authority prompted Kağitçibaşi to think 
more deeply about psychological explanations in non-Western cultures and conceptualisations based on Western understanding, which led her to focus on psychology in the non-West, i.e. in the Majority World. Kağitçibaşi (2007) pointed out the problematic way in which contemporary psychology is disseminated globally: models and theories are developed and established in North America and then transferred to and adopted by the rest of the world. Although she does not use the terms, this is of course precisely the neoliberal export of education that continues to reinvigorate neocolonial hegemony, which we identified in $§ 1$. Psychology struggles to strike a balance between scientific rigour and social relevance and while 'transferred knowledge' may have the appearance of the former, it is severely lacking in the latter (Kağitçibaşi 2007: 209). Kağitçibaşi warned psychologists of the need to recognise the importance of the external validity of theories, which should be tested for their cultural sensitivity and relevance. She (2017) also emphasised the need for a cultural lens through which human experiences and beliefs should be examined.

In Kağitçibaşi’s (2007) final monograph, Family, Self, and Human Development across Cultures: Theory and Applications, she presented a useful perspective on global education. The core of this perspective is the placing of the person in context, where the development of the self and personal competence are studied within the context of the individual's socioeconomic and cultural environment. The person in context provides at least two advantages with respect to teaching and learning in higher education. First, it draws attention to the need to either decolonise or deconstruct the curriculum: curriculum content and delivery must both take the different expectations, experiences, and beliefs produced by the context within which teaching and learning occurs into account in order to succeed. Second, it draws attention to the significance of sensitivity to context, which encourages students to reflect both on their acquisition of knowledge and on themselves, scrutinising the sources of their own beliefs and attitudes and broadening their intellectual horizons. Smele et 
al. (2017: 691) concur with Kağitçibaşi, highlighting how context, including 'materially and ideologically specific locations', shapes one's understanding and subjectivity.

Kağitçibaşi’s (2007) contextual-developmental-functional approach was initially applied to establish models of family and social change. Her models are based on the premise that the dynamic processes that link the person with the socioeconomic and cultural context are significant to the development of the self and understanding of the world. As such, the family is the context within which the person begins to develop a conceptualisation of the self and self in relation to others, and the conceptualisation continues to be shaped and influenced by the individual's interactions, socialisation, and environmental experiences. Kağitçibaşi's theory highlights the context-dependability of personhood and the development of the self in the context of the family is crucial in facilitating a method for research into lifespan studies, where person and context shape one another over time. This approach contrasts with psychology's current focus on the individual in both theory and practice. Kağitçibaşi's (2007: 129) research also provided a model of social change that opposed the 'convergence hypothesis' of modernisation theory: understanding lived experience and selfhood requires an understanding of the individual's context and culture and cannot be reduced to Western conceptions of social change and modernity, i.e. she emphasised the significance of studying developmental processes across cultures and on the development of concepts and theories originating from the Majority World. Kağitçibaşi $(1995 ; 2017)$ claimed that contributions to psychology by Majority World researchers fomented resistance to the Western epistemological hegemony and enhanced understanding. She (2007: 210) argued that this opposition to the 'individualistic stance of Western psychology' could help eliminate the bias that comes with the 'just world hypothesis', where social inequalities are naturalised. Kağitçibaşi's approach thus provides for the combination of local knowledge with flexibility and for self-reflection in the curriculum within which that knowledge is communicated. 
Gahman and Legault's (2017) definition of decolonial praxis offers support for Kağitçibaşi, indicating the importance of dynamic processes and reflexive methods in resistance against the unsettling mechanisms and everyday routines that maintain colonial social relations. Recognising the impact of the multiple and interrelated contextual factors that shape the socioeconomic and cultural context within which the individual exists is essential for both psychology as a discipline and teaching as a decolonised or deconstructed practice. In the final section, we apply Kağitçibaşi's contextual-developmental-functional approach to the deconstruction of the curriculum, demonstrating the need for work that prioritises sensitivity to context.

\section{Discussion: Deconstruction in Context}

Fanon provides a paradigmatic case study for two reasons: first, his oeuvre is exemplary in its sensitivity to context; and second, the marginalisation of that oeuvre identifies the need for the deconstruction rather than decolonisation of the curriculum because the circumstances of his life facilitated and exacerbated that marginalisation. The barriers to admitting Fanon to the canon discussed in $\S 3$ could be overcome by decolonising the curriculum and this seems to be, to at least some extent, what happened when Black Skin, White Masks was appropriated by postcolonial studies in the nineteen nineties (the inclusion of postcolonial studies in the literary studies curriculum is itself an example of decolonisation). The main problem with decolonising the curriculum is the pace at which the process has been implemented, noted in §2. If The Wretched of the Earth is, as Gibson (2011) suggests, relevant to the contemporary politics of post-apartheid South Africa, then it should be admitted to the political science curriculum (and perhaps others as well) in South African universities. This would be preferable to the book being left off the curriculum, but the feeding of previously neglected 
intellectuals into the curricula of various countries in the Global South on an ad hoc basis has not proved successful thus far. A more satisfactory solution is to introduce Fanon's oeuvre into the Global North curriculum - not for the explicit purpose of including a Global South perspective in the curriculum, but for the purpose of including a body of work which is particularly sensitive to context. This is, in a way, similar to what Hager, Peyrefitte and Davis (2018: 199) argue in their proposed pedagogy of 'critical locational encounter', that emphasises on the importance of diversity and difference in the world, and teaching methods that allow for critical and meaningful dialogue across groups. Like Hager et al. (2018) and other authors whose works oppose neoliberal education and academia, we believe that the curriculum should facilitate critical thinking by giving a special focus to different perspectives, contexts and viewpoints.

The publication of a critical forum on Fanon in the first 2018 issue of the journal College Literature reveals the sensitivity to context of his work. In her introduction, Harrison (2018: 2) writes:

While the present may not literally reflect the realities of colonization and imperialism as Fanon experienced and wrote about them, the continuities between his time and our own rest in the less obvious ways particular groups, peoples, and locales subordinate to the demands of neoliberal capitalist economics are kept in check by increasingly militarized domestic security forces.

Like Hudis (2015), Harrison and the other six contributors to the critical forum find Fanon relevant to racism and the Black Lives Matter movement in Trump's America - which comes as no surprise, given the popularity of The Wretched of the Earth with both the Black Power and Civil Rights movements in the US in the nineteen sixties. Moving beyond two specific periods of US history, however, Fanon's work is revealed as relevant in any context where particular groups, peoples, and locales subordinate to the demands of neoliberal capitalist 
economics are kept in check by increasingly militarized domestic security forces. In 33 , we noted that resistance to ready classification was one of the reasons for Fanon's exclusion from the (neocolonial) Global North curriculum and this lack of disciplinary fit seems to contribute to rather than detract from the applicability of his work to the different contexts in which the above circumstances exist. We do not wish to draw a general conclusion from a single example, but the relationship between resistance to disciplinary decadence and sensitivity to context is worthy of further study.

Kağitçibaşi presents a convincing argument for the significance of sensitivity to context, in both the practice of her discipline and in teaching in higher education. She invites academics to pay closer attention to cultural context, to rich cultural traditions that are not maintained for the sake of pre-modern nostalgia but because of their functional value within the socioeconomic environment. In her Value of Children Study, for example, Kağitçibaşi (2007) found that family ties and relatedness have retained their influence in Turkey despite recent rapid industrialisation. These findings present a challenge to the Western epistemological hegemony, in which the individuation-separation hypothesis predicts that the separateness of the self takes precedence over relatedness (which comes to be regarded as dependence) as modernisation proceeds. As such, the individuation-separation hypothesis provides a paradigmatic example of a theory that is not sensitive to context: modernisation is indeed a global phenomenon, but that phenomenon occurs in profoundly different contexts, in consequence of which there is a reciprocal relation between modernisation and culture.

Khoja-Moolji (2017) offers support for this claim and argues that attempts to present the hegemonic perspective of the individuated self as cross-cultural are detrimental to the development and implementation of education policies outside the West. Kağitçibaşi's study draws attention to the errors in the individuation-separation hypothesis and her contextualdevelopmental-functional approach provides an alternative vision, which facilitates in-depth, 
context-specific, and holistic analysis into the psyche and lived experiences of contemporary global citizens.

Sensitivity to context can be employed to distinguish all three of the curricula we have discussed: neocolonial, decolonised, and deconstructed. Where the neocolonial curriculum completely ignores context in favour of text (most often those written by dead white males) and the decolonised curriculum prioritises context (the local culture, circumstances, and commitments) over text, the deconstructed curriculum combines text and context, prioritising texts that can be applied to multiple contexts. Another way to understand this conception is the relationship between the universal and the particular: the neocolonial curriculum focuses on the universal (assuming that the culture, circumstances, and commitments of the Global North are universal), the decolonised curriculum focuses on the particular (the culture, circumstances, and commitments of a specific nation in the Global South), and the deconstructed curriculum focuses on the relationship between the universal and particular, the realisation of the global (text) in multiple particulars (contexts). The advantages of prioritising sensitivity to context - focusing on the relationship between text and context - are that it does not require a lengthy process of diversification and differentiation and that it employs the export of higher education from the Global North that is already in place. Because of the contemporary combination of neoliberalism and neocolonialism, even relatively minor changes to the Global North curriculum are likely to have a significant impact on the curricula of the Global South. To use examples from $\S 1$ and $\S 3$, including Fanon in the UK's curriculum would very quickly introduce his oeuvre to at least fifteen former colonies and Global South countries by means of the home-host relationship of international branch campuses.

Deconstructing the curriculum exploits the structure already in place (export from Global North to Global South) for its own subversive ends (democratising the curriculum) 
and contemporary scepticism (in the era of alternative facts) provides an unprecedented opportunity to pursue these ends. The questioning of authority that first drew attention to the colonised curriculum has been exacerbated by social-media-fuelled resistance to reactionary politics in both the US and UK, presenting a real opportunity to implement radical change in the Global North curriculum. The challenge is to acknowledge the lack of authority and use it to produce a more authoritative (because sensitive to context) curriculum. Kağitçibaşi has provided a methodology by which this change can be achieved, the contextualdevelopmental-functional approach to global education. The strategy we propose involves applying this approach to revise and reconstitute the Global North curriculum. This radical change would include, but of course not be restricted to, the admission of Fanon's work to the canon of several disciplines. Drawing back from the content of the curriculum received by the student in knowledge transfer, Kağitçibaşi's approach also foregrounds the significance of sensitivity to context in the academic mindset. Neither teaching nor research should be based on the uncritical appropriation of received wisdom: in the same way that teachers should encourage students to question the knowledge they transfer, so researchers should be questioning the channels into which their disciplines have corralled their research projects. It can be said that our proposal extends the call for a culturally relevant pedagogy as argued by scholars such as Lim, Tan and Saito (2019), especially as we provide specific guidelines for what that pedagogy can entail. We concur with Paris and Alim (2014) that a pedagogy we need is one that sustains pluralism in the society and fosters students to reflect not only on diversity but also diversity of thought. Sensitivity to context fosters critical thought and selfreflective practice, which in turn promote the democratisation of the individual and of the society of which that individual is a part.

We introduced globalisation in $§ 1$ in terms of Spivak’s double bind, which is part of her poststructural theory of aesthetic education. The double bind at the centre of global 
aesthetic education is that the neoliberal era of globalisation has both disseminated the humanities to more people than ever before and marginalised humanities students as a group of subjects that are not (economically, which is the only measure) useful to local, national, and global economies. While globalisation unquestionably provides new opportunities for aesthetic education, Spivak (2013: 288) is pessimistic about its long-term effects: 'If I have learned anything in my forty-five years of full-time teaching, it is the tragedy of the trivialization of the humanities, a kind of cultural death.' We are more optimistic about the prospects for a deconstructed Global North curriculum. The double bind at the centre of the neocolonial curriculum is that the neoliberal era of globalisation disseminates higher education to more of the Global South than ever before, but sustains and expands the ideological dominance of the Global North by means of that curriculum. The deconstruction of the Global North curriculum exploits the neoliberal apparatus already in place in order to replace the neocolonial curriculum. As such, it aligns the values of diversity, representativeness, and inclusivity with the pursuit of profit. This will ensure that democratisation remains viable until that happy time, if it ever arrives, when economic value is itself placed in context, as one of several values to be considered in curriculum development rather than the value that determines the worth of all other values.

\section{DECLARATION OF INTEREST STATEMENT:}

We have no interests to declare. 


\section{REFERENCE LIST:}

Aycan, Z. \& Cemalcilar, Z. (2018). Çiğdem Kağitçibaşi (1940-2017). American Psychologist, $73(1), 98$.

Beck, U. (1992/1986). Risk Society: Towards a New Modernity. Translated by M. Ritter. London: Sage.

Blake, A. (2017). Kellyanne Conway says Donald Trump's team has "alternative facts." Which pretty much says it all. The Washington Post, 22 January. Accessed 18 May 2018. Available at: <https://www.washingtonpost.com/news/the-fix/wp/2017/01/22/kellyanneconway-says-donald-trumps-team-has-alternate-facts-which-pretty-much-says-itall/?noredirect=on\&utm_term $=.2839 \mathrm{~b} 73 \mathrm{f5} 142>$.

Braidotti, R. (1991). Patterns of Dissonance: A Study of Women and Contemporary Philosophy. Cambridge: Polity.

Cherki, A. (2006/2000). Frantz Fanon: A Portrait. Translated by N. Benabid. Ithaca, NY: Cornell University.

Collins, H. (2017). Interculturality from above and below: Navigating uneven discourses in a neoliberal university system. Language \& Intercultural Communication, 18 (2), 167-183.

Derrida, J. (1997 [1967/1976]). Of Grammatology. Translated by G.K. Spivak. Baltimore: John Hopkins University Press.

— (2001 [1967/1978]) Writing and Difference. Translated by A. Bass. Abingdon: Routledge.

Fanon, F. (1965a/1961). The Wretched of the Earth. Tr. Constance Farrington. New York: Grove Weidenfeld.

— (1965b/1959). A Dying Colonialism. Tr. Haakon Chevalier. New York: Grove Press.

- (1967/1952). Black Skin, White Masks. Tr. Charles Lam Markmann. New York: Grove Press.

Foley, J. (2008). Albert Camus: From the Absurd to Revolt. Abingdon: Routledge.

Foucault, M. (2001 [1961/1967). Madness and Civilization: A History of Insanity in the Age of Reason. Translated by R. Howard. London: Routledge.

Gahman, L. \& Legault, G. (2017). Disrupting the settler colonial university: Decolonial praxis and placed-based education in the Okanagan Valley (British Columbia). Capitalism, Nature, Socialism. DOI: 10.1080/10455752.2017.1368680.

Geismar, P. (1971). Fanon: the Revolutionary as Prophet. New York: Grove Press.

Gibson, N.C. (2011). Fanonian Practices in South Africa: From Steve Biko to Abahlali baseMjondolo. New York: Palgrave Macmillan US.

Gibson, N.C. \& Beneduce, R. (2017). Frantz Fanon, Psychiatry and Politics. London: Rowman \& Littlefield International. 
Giddens, A. (1996). The Consequences of Modernity. Cambridge: Polity.

Gordon, L.R. (2014). Disciplinary Decadence and the Decolonisation of Knowledge. Africa Development XXXIX, 81-92.

- (2015). What Fanon Said: A Philosophical Introduction to His Life and Thought. London: Hurst \& Co.

Gyamera, G. O. \& Burke, P. J. (2018). Neoliberalism \& curriculum in higher education: A post-colonial analysis. Teaching in Higher Education, 23 (4), 450-467.

Hager, T., Peyrefitte, M. \& Davis, C. (2018). The politics of neoliberalism and social justice: Towards a pedagogy of critical locational encounter. Education, Citizenship \& Social Justice, 13(3), 199-206.

Haraway, D.J. (1991). Simians, Cyborgs, and Women: The Reinvention of Nature (New York: Routledge.

Harrison, S.M. (2018). Introduction: Fanon in the Present. College Literature, 45 (1), 1-9.

Hudis, P. (2015). Frantz Fanon: Philosopher of the Barricades. London: Pluto Press.

Kagitçibaşi, Ç. (1995). Is psychology relevant to global human development issues?

Experience from Turkey. American Psychologist, 50(4), 293.

- (2007). Family, Self, and Human Development across Cultures: Theory and Applications.

Mahwah: Lawrence Erlbaum Associates.

- (2017). Doing psychology with a cultural lens: A half-century journey. Perspectives on

Psychological Science, 12 (5), 824-832.

Khoja-Moolji, S. S. (2017). Envisioning an alternative to the neoliberalization of education in the global south: The Aga Khan's philosophies of education. Discourse: Studies in the Cultural Politics of Education, 38 (4), 542-560.

Lane, J.E. \& Kinser, K. (2017). Branch Campus Listing (Updated January 20). C-BERT, 20 January. Accessed 18 May 2018. Available at: <http://cbert.org/?page_id=34>.

Lin, L., Tan, M. \& Saito, E. (2019). Culturally relevant pedagogy: Developing principles of description and analysis. Teaching and Teacher Education, 77, 43-52.

Maslen, G. (2015). While branch campuses proliferate, many fail. University World News, 20 February. Accessed 18 May 2018. Available at:

<http://www.universityworldnews.com/article.php?story=20150219113033746>.

Macey, D. (2012). Frantz Fanon: A Biography. London: Verso.

Mercer-Maptsone, L. \& Mercer, G.(2018). A dialogue between partnership and feminism: Deconstructing power and exclusion in higher education. Teaching in Higher Education, 23 (1), 137-143.

Oliver, K. (1995). Womanizing Nietzsche: Philosophy's Relation to the “Feminine”. New York: Routledge. 
Paris, D. \& Alim, H. (2014). What are we seeking to sustain through culturally sustaining pedagogy? A loving critique forward. Harvard Educational Review, 84(1), 85-100.

Pirelli, G. \& Love R.E. (2015). Biographical Note on Frantz Fanon. Interventions: International Journal of Postcolonial Studies, 17 (3), 394-416.

Poortinga, Y.H. (2018). A majority world perspective on human development: Commemorating the achievements of Çiğdem Kağitçibaşi, European Journal of Developmental Psychology, 15 (2), 131-138.

Shahjahan, R. A. (2014). From 'non' to 'yes': Postcolonial perspectives on resistance to neoliberal higher education. Discourse: Studies in the Cultural Politics of Education, 35 (2), 219-232.

Smele, S., Siew-Sarju, R., Chou, E., Breton, P. \& Bernhardt, N. (2017). Doing feminist difference differently: Intersectional pedagogical practices in the context of the neoliberal diversity regime. Teaching in Higher Education, 22 (6), 690-704.

Spivak, G.C. (2013). An Aesthetic Education in the Era of Globalization. Cambridge, MA: Harvard University Press.

University of Oxford International Strategy Office (2015). International Trends in Higher Education 2015. Accessed 18 May 2018. Available at:

<https://www.ox.ac.uk/sites/files/oxford/International\%20Trends\%20in\%20Higher\%20Educ ation\%202015.pdf $>$.

Webber, J. (2018). Rethinking Existentialism. Oxford: Oxford University Press.

Winberg, S. \& Winberg, C. (2017). Using a social justice approach to decolonize an engineering curriculum. 2017 IEEE Global Engineering Education Conference (EDUCON). Available at: <https://ieeexplore.ieee.org/document/7942855/>. 